\title{
Effects of Maternal Parenting Behavior and Preschoolers' Executive Function on Preschoolers' Theory of Mind
}

\author{
Moonyoung Jang, Nana Shin \\ Department of Child Development \& Intervention, Ewha Womans University, Seoul, Korea \\ 어머니의 양육행동과 유아의 실행기능이 유아의 마음이론에 미치는 영향 \\ 장문영, 신나나 \\ 이화여자대학교 아동학과
}

Objective: The main purposes of this study were to examine the effects of maternal parenting behavior on preschoolers' theory of mind and to explore the role of executive function in the process.

Methods: A total of 403 preschoolers between the ages of 3 and 5 years and their mothers participated in this study. Mothers responded to a questionnaire that included items from Parenting Behavior Scale, Behavior Rating Inventory of Executive Function-Preschool Version (BRIEF-P), and Children's Social Understanding Scale (CSUS).

Results: Results indicated that maternal parenting behavior did not have a direct effect on preschoolers' theory of mind. In contrast, the indirect effect of maternal parenting behavior on preschoolers' theory of mind through executive function was significant. In other words, positive parenting behavior led to higher levels of executive function, and as the level of preschooler's executive function was higher, the preschoolers showed higher levels of theory of mind.

Conclusion: The findings indicate that in addition to laboratory assessments of performance of executive function and theory of mind, parent-report measures may be useful as an additional source of information about individual differences in executive function and theory of mind. The relations between executive function and theory of mind during the preschool period and their developmental origins are highlighted in the discussion.

Keywords: maternal parenting behavior, executive function, theory of mind

\begin{abstract}
서론
인간은 생애 초기 가족과 관계를 맺는 것을 시작으로 또래나 교사와 관계를 맺고, 이후 성인이 되어서도 자신이 속한 집단 에서 끊임없는 사회적 관계를 형성하며 살아간다. 따라서 사 회적 관계 속에서의 적응은 매우 중요하며, 이를 위해서 필수 적으로 요구되는 능력이 상호작용 시 타인의 생각이나 감정을

Corresponding Author: Nana Shin, Department of Child Development \& Intervention, Ewha Womans University, 52, Ewhayeodae-gil, Seodaemungu, Human Ecology Building 402-1, Seoul, 03760, Korea

E-mail: nanashin@ewha.ac.kr
\end{abstract}

이해하는 능력이다. 마음이론(theory of mind)은 이러한 맥락 에서 대두된 개념으로 자신과 타인의 믿음, 바람이나 감정과 같은 마음상태가 행동을 설명하고 예측할 수 있다는 것을 이 해하는 능력을 의미한다. 마음이론이라는 용어는 Premack과 Woodruff (1978)의 침팬지 대상 연구에서 처음 사용되었으며, 유아를 대상으로 한 연구는 1980년대부터 이루어지기 시작하 였다(Wimmer \& Perner, 1983). 국내에서는 1990년대 후반부

C)The Korean Association of Child Studies

This is an Open Access article distributed under the terms of the Creative Commons Attribution Non-Commercial License (http:// creativecommons.org/licenses/by-nc/4.0) which permits unrestricted noncommercial use, distribution, and reproduction in any medium, provided the original work is properly cited. 
터 마음이론에 대한 연구가 나타나기 시작하여(Ghim, 1997; Song, 1999), 최근에는 마음이론의 기원 및 발달적 결과에 관 한 연구가 활발하게 진행되고 있다(Chi \& Kim, 2015; Chung, 2011; H. Lee, 2013; S.-J. Lee, 2012; Y.-M. Lee et al., 2015). 이러 한 연구들을 통해 유아기 동안 마음상태에 대한 이해가 급격 하게 발달하며(Harris, 2006), 유아기 마음이론이 이 시기뿐 아 니라 이후의 적응과 발달에 영향을 미친다는 것이 확인되었 다(Ahn, Kim, \& Lee, 2012; Cassidy, Werner, Rouke, Zubernis, \& Balaraman, 2003; Y.-M. Lee et al., 2015).

유아의 마음상태에 대한 이해를 살펴본 대부분의 연구들은 바람, 감정, 믿음, 의도, 인식과 같은 마음상태에 대한 이해를 측정하기 위해 틀린믿음과제(Wimmer \& Perner, 1983), 외양실 제과제(Flavell, Flavell, \& Green, 1983), 정서이해과제(Hadwin, Baron-Cohen, Howlin, \& Hill, 1996) 등과 같이 실험실 상황에 서 과제를 제시하고 유아의 수행을 측정하는 데 초점을 두어 왔다. 이러한 연구들은 마음이론의 발달적 변화 및 관련 변인 에 대한 광대한 자료를 제공하며 그 유용성을 입증하였지만, 몇몇 측면에서의 제한점 또한 제기되었다. 예를 들어, Hughes 등(2000)은 9가지 틀린믿음 과제 간 측정-재측정 신뢰도를 카 파(Kappa) 계수로 살펴본 결과 .29에서.72까지 다양하게 나타 나 신뢰도 측면에서 일관적이지 않음을 밝혔다. 또한 인간의 마음상태에 대한 이해는 광범위하고 다측면적인데 비해, 현재 측정되고 있는 마음이론 과제는 주로 틀린 믿음에 초점을 두 고 있어 바람, 의도, 정서, 지각 및 지식에 대한 이해를 간과하 고 있다는 제한점도 제기되었다. 마지막으로, 실험실 상황에 서의 과제 수행은 생태학적 타당도(ecological validity)가 높지 않다는 점이 지적되면서 아동이 일상생활에서 보이는 행동이 나 의사소통, 상호작용에 반영된 마음상태에 대한 이해를 측 정할 필요성 또한 제기되었다. 이러한 제한점을 보완하기 위 하여 Tahiroglu 등(2014)은 실험실 상황이 아닌 아동이 일상생 활에서 보이는 마음이론을 부모보고를 통해 측정하는 아동의 사회적 이해 척도(Children's Social Understanding Scale [CSUS]) 를 개발하였다. CSUS는 믿음, 지식, 인식, 바람, 의도, 감정의 6 가지 측면의 마음상태에 대한 이해를 측정하도록 고안되었으 며, Tahiroglu 등(2014)은 과제 수행을 통한 마음이론 점수와 유 의한 상관을 보고하며 척도의 타당성을 입증하였다.

마음이론의 발달과 관련된 변인으로 여러 연구들에서 보고 된 실행기능은 목표를 달성하기 위해 의식적으로 자신의 행동 이나 사고, 정서를 조절하고 관리하는 고차원적인 인지능력을 의미하는 것으로(Welsh, Pennington, \& Groisser, 1991; Zelazo $\&$ Müller, 2002), 특히 유아기 동안 급격하게 발달하는 것으로
여러 연구들에서 보고되었다(Carlson, 2005; Jacques \& Zelazo, 2001; Shin, 2005). 실행기능은 여러 요소를 가진 다차원적인 개념으로, 억제 통제(inhibitory control), 주의 전환(attentional shift), 작업기억(working memory), 계획 능력(planning)등이 이 에 포함된다. 유아기 실행기능을 측정하기 위한 다양한 과제 들 또한 고안되었는데, 대표적으로 낮/밤과제(Gerstadt, Hong, \& Diamond, 1994), 카드분류과제(Frye, Zelazo, \& Palfai, 1995), 하노이의 탑 과제(Welsh, 1991)등이 있다. 또한 마음이론과 유사하게 유아가 실험실 상황에서 보이는 수행이 일상생활 에서의 실행기능으로 일반화될 수 있는지에 대한 논의가 제 기되면서(Toplak, West, \& Stanovich, 2013), 실행기능을 측정 하기 위한 행동 평정 척도가 개발되어(Gioia, Isquith, Guy, \& Kenworthy, 2000; Isquith, Gioia, \& Espy, 2004) 널리 사용되고 있다(Y.-J. Lee, Kong, \& Lim, 2014; Seo \& Park, 2011).

유아기 실행기능과 마음이론 간 관련성은 여러 연구들에 서 보고되고 있는데, Carlson과 Moses (2001)는 두 능력이 모두 3-5세 사이 발달적 전환을 보이고(Wellman, Cross, \& Watson, 2001), 전두엽이라는 공통된 대뇌 영역이 그 발달을 담당하며 (Sabbagh \& Taylor, 2000), 자폐증을 가진 아동에게 두 가지 능 력이 모두 결여되어 있다는 점(Rakoczy, 2010)을 그 근거로 제 시하였다. 두 변인 간 관계를 살펴본 연구들(Carlson \& Moses, 2001; Carlson, Moses, \& Claxton, 2004)에서는 실행기능의 하 위요인 중 억제, 전환, 계획 능력이 높을수록 틀린 믿음에 대한 이해 수준이 더 높은 것으로 보고하였다. 관련 연구들이 축적 되면서 최근 Devine과 Hughes (2014)는 3-6세 유아를 대상으로 실행기능과 틀린 믿음 간 관계를 살펴본 102 편에 대한 메타분 석을 실시하였다. 그 결과, 유아기 실행기능과 마음이론 간 관 련성이 입증되었으며, 문화적인 보편성을 가지고 있음이 확인 되었다. 반면 국내에서 실시된 연구들은 실행기능과 마음이론 간 관계에 대해 다소 일관되지 않은 결과를 보고하고 있다. 즉, 실행기능이 높을수록 마음이론이 높은 것으로 나타난 연구들 (H. Lee, 2013; J. Lee, 2005; Shin, 2005)도 있지만, 실행기능과 마음이론 간 관련성을 발견하지 못한 연구들(H. Lee, 2011; Oh \& Lewis, 2008; Yoo \& Park, 2008) 또한 보고되고 있다. 실행기 능과 마음이론 간 관련성을 밝히지 못한 연구들에서는 국내 유아들이 서구 유아들에 비해 실행기능 과제에서는 높은 수준 의 수행을 보이는데 반해 마음이론 과제에서는 저조한 수행을 보이기 때문인 것으로 해석하였다.

실행기능과 마음이론 간 관계를 살펴보는 데 있어 또 다른 쟁점은 실행기능과 마음이론 중 어떠한 변인이 선행하는 변 인인지에 대한 것이다. 마음이론의 발달이 실행기능의 발달 
에 선행한다고 보는 입장(Perner, 1991)에서는 유아가 그림이 나 언어와 같은 표상적 특성을 이해하고 외양과 실재를 구분 하게 되면서 마음이론이 발달하고, 그 결과 작업 기억과 억제 통제와 같은 실행기능이 발달하게 된다고 주장하였다. 반면 Russell (1996)은 이미 알고 있는 사실을 억제하거나, 자신의 입 장에서 타인의 입장으로 전환하는 실행기능이 발달해야 마음 이론 과제를 성공적으로 수행할 수 있는 것으로 보았다. 최근 에 실시된 연구들은 이러한 방향성에 대한 논란에 어느 정도 해결책을 제시하고 있는데, 종단연구를 통해 마음이론과 실행 기능 간 관련성을 살펴본 연구들(Carlson, Mandell, \& Williams, 2004; Hughes \& Ensor, 2007)에서는 유아기 실행기능이 발달 할수록 이후 마음이론 수준이 높은 것으로 나타나 실행기능이 마음이론에 선행하는 요인임을 제안하였다. 또한 유아에게 실 행기능 훈련을 수행한 결과 5세 아동의 틀린 믿음에 대한 이해 가 향상되었으며(Y.-M. Lee \& Park, 2008), 유아의 실행기능에 서의 개인차가 훈련을 통한 마음이론의 향상을 예측하는 것으 로 나타나(Benson, Sabbagh, Carlson, \& Zelazo, 2013) 실행기능 이 마음이론 발달에 영향을 미친다는 것을 지지하였다.

실행기능과 마음이론의 발달은 환경적 요인에 의해 영향을 받으며, 이 중에서도 어머니의 양육행동은 두 변인 모두에 영 향을 미치는 요인으로 알려져 왔다. 먼저 어머니의 양육행동 이 유아의 마음이론에 미치는 영향과 관련하여, Viden (2001) 은 자유로운 의사소통이 이루어지는 민주적 관계에서는 유아 가 다양한 관점을 사고하여 자신의 행동을 결정하는데 반영 하기 때문에 마음이론 발달이 촉진되지만, 강압이나 지나친 개입을 사용하는 등 부모가 권위주의적 양육행동을 보일 경 우 자녀는 다양한 관점으로 세상을 바라보는 것이 아닌 부모 의 관점만을 받아들이도록 강요되기 때문에 마음이론의 발달 이 지연될 수 있다고 하였다. 구체적인 연구결과들을 살펴보 면, 부모가 엄격하고 통제적인 양육행동인 권위주의적인 양육 행동을 보일수록 유아는 바람과제, 믿음과제, 정서과제 등을 통해 측정한 마음이론에서 낮은 수준을 보였다(Pears \& Moses, 2003; Vinden, 2001). 또한, 어머니가 아동에 대해 일방적인 질 책을 보이거나(Ruffman, Perner, \& Parkin, 1999), 신체적, 언어 적으로 강압적인 양육행동을 보일수록 유아의 틀린믿음과제 수행률이 낮았다(Pears \& Moses, 2003). 반면 어머니가 자녀에 게 민감하게 반응하고(Symons \& Clark, 2000), 논리적인 설명 과 애정적 양육행동을 더 보일수록(Bae \& Choi, 2002) 유아는 상황 및 타인에 대한 이해를 더 잘하였다.

어머니의 양육행동은 또한 유아의 실행기능에도 영향을 미 치는 것으로 보고되고 있는데, 어머니가 자녀의 활동에 지지
적이고 일관적인 양육행동을 보일수록 유아의 실행기능 수준 이 높았다(Hughes \& Ensor, 2009). 이와 유사한 맥락에서 어머 니가 자율성을 지지하고, 애정적인 양육행동을 보일수록 양과 호랑이 과제, 만족지연과제, 8 개의 상자 과제와 같은 실행기 능 과제에서 더 나은 수행을 보일 뿐만 아니라 부모가 평가한 실행기능에서도 더 높은 점수가 나타났다(Y.-J. Lee et al., 2014; Moon \& Shin, 2017). 반면, 어머니가 적대적인 태도를 보이 거나, 과보호를 할 경우에는 유아의 실행기능 수준이 낮았다 (Graziano, 2009). 또한 어머니가 비일관적인 양육행동을 보일 수록 4세 유아가 작업기억, 전환, 억제와 같은 실행기능 과제 에서 낮은 수행을 보였다(Hughes \& Ensor, 2009). 이에 더해 최 근 실시된 종단연구들(Bernier, Carlson, \& Whipple, 2010; Blair et al., 2011; Blair, Raver, Berry, \& Family Life Project Investigators, 2014; Hammond, Müller, Carpendale, Bibok, \& LiebermannFinestone, 2012)은 초기 어머니의 양육행동이 이후 유아의 실 행기능을 예측한다는 결과들을 보고하면서, 어머니의 양육행 동이 유아기 실행기능의 발달에 중요한 역할을 담당한다는 보 다 직접적인 증거를 제시하였다. 이처럼 어머니의 양육행동은 유아의 마음이론과 실행기능의 발달에 영향을 미치는 중요한 요인임을 선행 연구들을 통해서 확인할 수 있다.

종합하면, 유아기 실행기능은 마음이론과 밀접하게 관련 되며, 실행기능과 마음이론 발달을 촉진하는 환경적 요인으 로서 어머니의 양육행동의 중요성은 여러 연구들에서 입증되 어 왔다. 즉, 개인적 측면에서 유아의 실행기능과 환경적 측면 에서 어머니의 양육행동은 유아기 마음이론 발달을 위한 중 요한 변인임을 알 수 있다. 선행연구들은 어머니의 양육행동 이 유아의 실행기능 혹은 마음이론에 미치는 영향을 살펴보았 지만, 세 변인을 모두 포함하여 관련성을 살펴본 연구는 찾아 보기 어렵다. 본 연구에서는 유아기 동안 실행기능이 마음이 론의 발달에 선행하며(Benson et al., 2013; Carlson et al., 2004; Hughes \& Ensor, 2007; Y.-M. Lee \& Park, 2008), 어머니의 양 육행동이 유아의 마음이론과 실행기능 발달에 영향을 미치는 요인임을 밝힌 연구들(Blair et al., 2014; Hammond et al., 2012; Viden, 2001)에 근거하여 어머니의 양육행동이 실행기능을 통 해 마음이론에 미치는 영향을 살펴보았다. 즉, 만 3-5세 유아 를 대상으로 어머니의 양육행동이 유아의 마음이론에 미치는 직접적 영향과 실행기능을 통한 간접적 영향을 살펴봄으로써 유아기 마음이론 향상을 위한 개인적 측면과 환경적 측면에서 의 구체적 방안을 탐색해 보고자 하였다. 또한 실행기능과 마 음이론을 살펴본 대부분의 연구가 실험과제를 중심으로 이루 어져 일상생활에서 적용되는 실행기능과 마음이론에 대한 탐 
색이 부족하다는 점에 착안하여, 본 연구에서는 어머니 보고 를 통해 실행기능과 마음이론을 측정한 후 두 변인 간 관계를 살펴보았다. 본 연구의 연구문제와 연구모형(Figure 1)은 다음 과 같다.

\section{연구문제 1}

어머니의 양육행동이 유아의 마음이론에 미치는 직접적 영향 은 어떠한가?

\section{연구문제 2}

어머니의 양육행동이 유아의 실행기능을 통해 마음이론에 미 치는 간접적 영향은 어떠한가?

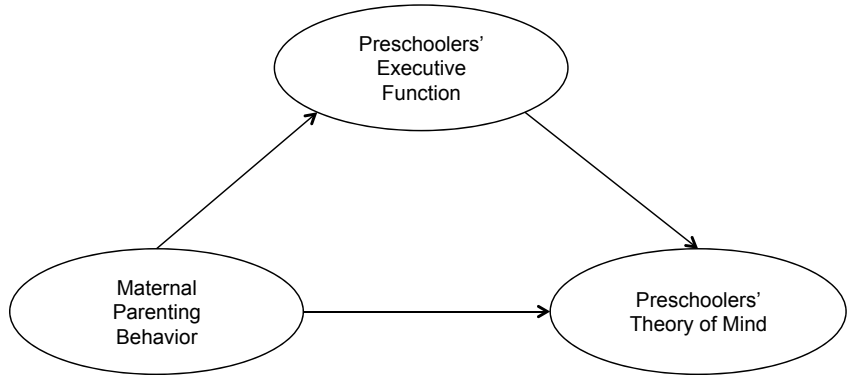

Figure 1. The hypothesized research model.

\section{연구방법}

\section{연구대상}

본 연구의 대상은 만 3-5세 유아 403명과 그들의 어머니이다. 이 중 329명의 유아와 어머니의 자료는 온라인 조사업체를 통 해 자료를 수집하였으며, 74 명의 유아와 어머니의 자료는 질 문지를 직접 배부하고 회수하는 방식으로 자료를 수집하였 다. 두 집단 간 어머니의 양육행동, 유아의 마음이론 및 실행 기능에 차이가 있는지 살펴보기 위해 독립표본 $t$ 검정을 실시 한 결과 두 집단 간 유의한 차이는 나타나지 않았다. 본 연구 에서 만 3-5세 유아를 연구대상으로 선정한 이유는 실행기능 (Hongwanishkul, Happaney, Lee, \& Zelazo, 2005; Y.-J. Lee et al., 2014)과 마음이론(Carlson \& Moses, 2001; H. Lee, 2011)이 유 아기 동안 급격하게 발달되며, 특히 만 4세 전후가 실행기능과 마음이론 발달의 민감기라고 제안한 선행연구들(Shin, 2005; Wellman et al., 2001)에 근거하였다.

연구대상의 사회인구학적 특성을 살펴보면, 유아의 성별
은 여아 203명(50.4\%), 남아 200명(49.6\%)이었고, 연령은 만 3 세 120명(29.8\%), 만 4세 144명(35.7\%), 만 5세 139명(34.5\%) 이었다. 출생순위는 외동이가 187 명 $(46.4 \%)$ 으로 가장 많았고, 첫째가 128 명(31.7\%), 둘째가 75명(18.6\%), 셋째 이상이 13명 (3.2\%)이었다. 어머니의 연령은 30-39세가 263명(65.3\%)으로 가장 많았고, 그 다음으로 40-49세 79명(19.6\%), 20-29세 48 명(11.9\%), 50세 이상 12 명(3.0\%), 무응답 1 명 $(0.2 \%)$ 순이었 다. 어머니의 교육수준은 대학교 졸업이 249 명 $(61.8 \%)$ 으로 가 장 많았고, 그 다음이 전문대 졸업 또는 대학교 중퇴가 76명 (18.9\%), 대학원 졸업 45명(11.2\%), 고등학교 중퇴 또는 졸업 32 명(7.9\%), 중학교 중퇴 또는 졸업 1 명 $(0.2 \%)$ 순이었다. 비취 업모가 140 명(34.7\%), 취업모가 263명(65.3\%)으로 취업모가 더 많았다.

\section{연구도구}

본 연구의 조사도구는 어머니의 양육행동, 유아의 실행기능 및 마음이론을 측정하기 위한 세 가지 척도로 이루어져 있으 며, 모두 어머니 보고로 측정되었다. 모든 문항은 전혀 그렇지 않다(1점), 그렇지 않은 편이다(2점), 그런 편이다(3점), 매우 그렇다(4점)의 4점 Likert식 척도로 응답되었다.

\section{어머니의 양육행동}

어머니의 양육행동은 Rhee (2012)가 초등학교 저학년 자녀를 둔 부모를 대상으로 제작한 양육행동 척도를 $\mathrm{Na}$ (2012)가 유 아기에 적절하게 수정한 척도를 사용하여 측정하였다. 본 척 도는 온정(9문항), 논리적 설명(10문항), 개입(9문항), 강압(7 문항), 방임(10문항)의 다섯 가지 하위요인으로 구성되어 있 으며, 총 45 문항이다. 각 하위요인의 문항의 예를 살펴보면, 온정은 “웃는 얼굴로 아이를 대해준다.", "아이와 함께 따뜻 하고 친밀한 시간을 보낸다.” 등이, 논리적 설명은 "아이에게 규칙을 지켜야 하는 이유를 설명해준다.”, “아이가 무리한 요 구를 하면 왜 안 되는지 그 이유를 말해준다.”등이 있다. 개입 의 문항의 예로는 "아이가 하는 일을 잠자코 보지 못하고 간 섭을 한다.", "아이의 행동이 내 기대에 부합하지 않을 때 꾸짖 거나 나무란다.” 등이 있으며, 강압은 "아이가 말을 듣지 않을 때 찰싹 때린다.", "이유를 설명하기 보다는 벌로써 아이를 지 도한다.” 등의 문항을 그 예로 들 수 있다. 마지막으로, 방임에 는 "아이가 이유 없이 유치원(어린이집)에 결석해도 내버려둔 다.", "아이에 대해 관심이 없어서 칭찬하거나 혼내는 일이 없 
다.” 등의 문항이 포함된다. 각 하위요인의 점수가 높을수록 그 요인의 특성이 높음을 의미하며, 각 하위요인의 내적합치 도(Cronbach's $\alpha$ )는 온정 .85 , 논리적 설명 .84 , 개입 .86 , 강압 .85 , 방임 .92 이었다.

\section{실행기능}

실행기능을 측정하기 위해 Gioia 등(2000)이 개발한 행동 평 정 척도를 유아용으로 수정하여 타당화한 Isquith 등(2004)의 척도(Behavior Rating Inventory of Executive Function-Preschool version [BRIEF-P])를 Seo와 Park (2011)이 번안한 척도를 사용 하였다. 본 척도는 총 63문항으로 억제(16문항), 전환(10문항), 감정조절(10문항), 작업 기억(17문항), 계획 및 조직화(10문 항)의 5 가지 하위요인으로 구성되어 있다. 억제의 문항의 예 로는 "생일파티나 놀이상황 등에서 다른 아이들에 비해 더 과 격하게 행동하거나 바보스럽게 굴 때가 있다.", "잠시도 가만 히 있지 못한다.” 등이 있다. 전환은 “새로운 장소나 상황(먼 친척이나, 새로운 친구의 방문 등)에서 편안함을 느끼기까지 오랜 시간이 걸린다.", “새로운 상황에 접하면 혼란스러워 한 다.” 등의 문항을 예로 들 수 있다. 감정조절의 문항의 예로는 “화가 나면 폭발적으로 감정을 분출한다.", "작은 일에도 큰 반 응을 일으킨다." 등이 있다. 작업 기억은 "두 가지 일을 주면, 한 가지만 기억한다.", "잠시만 지나도 어떤 것을 기억하는 것 에 어려움이 있다.” 등의 문항을 예로 들 수 있다. 마지막으로 계획 및 조직화의 문항의 예로는 “청소를 하라고 지시하면, 물 건들을 두서없이 비조직적으로 치운다.", “지시를 해도 과제 를 완성하지 않는다.” 등이 있다.

원문항이 점수가 높을수록 실행기능이 낮은 것을 의미하도 록 구성되어 있어, 모든 문항을 역채점하여 점수가 높을수록 실행기능의 각 요인의 특성이 높도록 변환하였다. 각 하위요 인의 내적합치도(Cronbach's $\alpha$ )는 억제 .93, 전환 .88, 감정조절 .88 , 작업기억 .94 , 계획 및 조직화 .88이었다.

\section{마음이론}

마음이론을 측정하기 위해 Tahiroglu 등(2014)이 개발한 아 동의 사회적 이해 척도(Children's Social Understanding Scale [CSUS])를 본 연구의 제 1저자가 번역하였으며, 영어와 한국 어에 능통한 이중언어자가 이를 다시 역번역한 후 원문을 대 조하여 수정하였다. 이를 아동학 전문가들(아동학 전공 교수 1 명, 아동학 박사 1 명)이 최종 검토한 후 사용하였다. 본 척도
는 총 42 문항으로 믿음, 지식, 인식, 바람, 의도, 감정의 6가지 하위요인으로 구성되어 있다. 믿음(7문항)의 문항의 예로는 "자신의 믿음이 시간이 지나면서 어떻게 변화하였는지에 관 하여 이야기 한다.”, “다른 사람과 자신의 믿음이 어떻게 다른 지 이야기 한다.” 등이 있다. 지식(7문항)은 "자신보다 더 어린 아이에게 설명해 주는 것에 능숙하다.", "가르치고 배운 것에 대해 이야기 한다.” 등의 문항을 예로 들 수 있다. 인식(7문항) 의 문항의 예로는 "사람들이 보거나 듣는 것에 대해 이야기 한 다.”, “쉽게 들통 날 수 있는 거짓말을 한다.” 등이 있다. 바람(7 문항)은 “사람들이 원하는 것과 실제 얻게 되는 것 간의 차이 점에 대해 이야기한다.”, "바라는 것이 항상 이루어지는 것은 아니라는 것을 이해한다." 등의 문항을 예로 들 수 있다. 의도 (7문항)의 문항의 예로는 "의도적으로 하는 것과 실수로 하는 것 사이의 차이점에 대해 이해한다.", "놀림을 당하거나 웃음 거리가 되었을 때 그 상황을 알아차린다.” 등이 있다. 감정(7문 항)에는 "바라지 않았던 선물을 받았을 때, 준 사람의 기분이 상하지 않도록 좋아하는 척을 한다.”, "자신이 잘못을 하면 다 른 사람이 화를 낼 수도 있다는 것을 깨닫는다." 등의 문항이 포함된다.

각 하위요인의 점수가 높을수록 요인의 특성이 높음을 의 미한다. 각 하위요인의 내적합치도(Cronbach's $\alpha$ )는 믿음 .71, 지식 .78, 인식 .26 , 바람 .75 , 의도 .70, 감정 .63이었다. 인식의 경우 내적합치도가 낮아 분석에는 포함되지 않았다.

\section{연구절차}

본 연구의 자료 수집을 위해 온라인 $(N=329)$ 과 오프라인 $(N$ = 74)을 통해 설문조사를 실시하였다. 먼저 온라인을 통한 자 료수집은 2015년 9월에 온라인 조사업체를 통해 실시되었다. 리서치업체의 패널은 성별, 연령, 지역 분포가 전국 인구분포 와 유사하게 구성되어 있으며, 등록되어 있는 인구학적 특성 을 바탕으로 자녀가 있는 여성에게만 이메일로 질문에 응답할 수 있는 링크가 선별적으로 발송되었다. 사전 선별 질문으로 만 3-5세 자녀가 있는지를 조사하여 이에 해당하지 않는 경우 응답이 자동 종료되도록 하였다. 또한 불성실한 응답을 줄이 기 위하여, 하나의 문항에 응답한 후에 다음 문항이 나올 수 있 도록 구성하였다. 오프라인을 통한 자료수집은 2015년 10-12 월에 서울시에 거주하는 어머니들을 대상으로 실시되었으며, 인터넷 육아 카페에 공고문을 게시하고, 공고문에 남긴 전화 와 이메일로 연구 참여에 관심을 보인 어머니들에게 질문지를 배부한 후 회수하였다. 두 경우 모두 만 3-5세 자녀가 2명 이상 
Table 1

Age Differences in Maternal Parenting Behavior, Preschoolers' Executive Function and Theory of Mind

\begin{tabular}{|c|c|c|c|c|c|c|c|c|}
\hline & \multicolumn{2}{|c|}{$\begin{array}{c}3 \text {-year-old } \\
(n=120)\end{array}$} & \multicolumn{2}{|c|}{$\begin{array}{l}\text { 4-year-old } \\
(n=144)\end{array}$} & \multicolumn{2}{|c|}{$\begin{array}{l}\text { 5-year-old } \\
(n=139)\end{array}$} & \multirow[b]{2}{*}{$F$} & \multirow[b]{2}{*}{ Scheffé } \\
\hline & M & $S D$ & $M$ & $S D$ & $M$ & $S D$ & & \\
\hline Warmth & 3.15 & 0.42 & 3.15 & 0,41 & 3.04 & 0.42 & $3.46^{*}$ & \\
\hline Logical reasoning & 3.07 & 0.34 & 3.16 & 0.37 & 3.13 & 0.36 & 2.41 & \\
\hline Neglect & 1.54 & 0.48 & 1.46 & 0.54 & 1.46 & 0.52 & 1.01 & \\
\hline \multicolumn{9}{|l|}{ Executive function } \\
\hline Inhibit & 3.09 & 0.45 & 3.17 & 0.49 & 3.14 & 0.53 & 0.82 & \\
\hline Shifting & 3.00 & 0.51 & 3.06 & 0.50 & 3.07 & 0.55 & 0.64 & \\
\hline \multicolumn{9}{|l|}{ Theory of mind } \\
\hline Belief & $2.42^{\mathrm{a}}$ & 0.44 & $2.63^{b}$ & 0.38 & $2.66^{\mathrm{b}}$ & 0.42 & $12.88^{* * *}$ & $\mathrm{a}<\mathrm{b}$ \\
\hline Knowledge & $2.68^{\mathrm{a}}$ & 0.40 & $2.88^{\mathrm{b}}$ & 0.45 & $2.95^{\mathrm{b}}$ & 0.50 & $12.23^{* * *}$ & $a<b$ \\
\hline Desire & $2.66^{\mathrm{a}}$ & 0.40 & $2.85^{\mathrm{b}}$ & 0.41 & $2.89^{\mathrm{b}}$ & 0.44 & $11.20^{* * *}$ & $a<b$ \\
\hline Intention & $2.63^{\mathrm{a}}$ & 0.40 & $2.82^{\mathrm{b}}$ & 0.38 & $2.83^{\mathrm{b}}$ & 0.44 & $10.05^{* * *}$ & $a<b$ \\
\hline Emotion & $2.70^{\mathrm{a}}$ & 0.32 & $2.84^{\mathrm{b}}$ & 0.40 & $2.88^{\mathrm{b}}$ & 0.41 & $8.03^{* * *}$ & $a<b$ \\
\hline
\end{tabular}

Note. $N=403$. Scheffé contrasts are significant at the .05 level.

${ }^{*} p<.05 .{ }^{* * *} p<.001$.

있을 경우에는 첫째를 기준으로 응답하도록 하였다. 정규성을 검정하기 위하여 왜도와 첨도를 살펴본 결과 왜도의 절대값은 $0.06 \sim 1.32$, 첨도의 절대값은 $0.08 \sim 1.86$ 으로 왜도와 첨도 모 두 2보다 작아 정규성 기준을 충족하였다(Kline, 2015).

\section{자료분석}

수집된 자료는 SPSS 21.0 (IBM Co., Armonk, NY)과 AMOS 18.0 (IBM Co., Armonk, NY)을 사용하여 분석하였다. 먼저, 연구대상의 사회인구학적 특성을 알아보기 위해서 빈도분석 을 통해 빈도와 백분율을, 조사 도구의 신뢰도를 알아보기 위 해 내적합치도 계수인 Cronbach's $\alpha$ 를 산출하였다. 예비 분석 으로 연령에 따라 어머니의 양육행동, 유아의 실행기능 및 마 음이론에 차이가 있는지 살펴보기 위해 일원분산분석을 실시 하였다. 또한 측정 변인들 간의 관계를 살펴보기 위해 연령을 통제한 편상관계수를 산출하였다. 어머니의 양육행동, 유아 의 실행기능 및 마음이론 간의 구조적 관계를 살펴보기 위해 먼저 잠재변인이 측정변인을 잘 설명하고 있는지 확인적 요
인분석을 통해 검증한 후, 구조방정식 모형(Structural Equation Modeling [SEM])을 분석하였다. 모형의 적합도는 $\chi^{2}$ 와 NFI, TLI, CFI, RMSEA를 통해 평가되었으며, 어머니의 양육행동이 유아의 실행기능을 통해 유아의 마음이론에 미치는 간접효과 가 유의한지 여부는 부트스트랩핑 방법을 통하여 검증하였다.

\section{연구결과}

\section{예비분석}

유아의 연령에 따라 어머니의 양육행동, 유아의 실행기능 및 마음이론에 차이가 있는지 살펴보기 위하여 일원분산분석을 실시하였다(Table 1). 먼저 어머니의 양육행동의 경우, 유아의 연령에 따라 어머니가 보이는 온정 $(F=3.46, p<.05)$ 과 개입 $(F$ $=4.57, p<.05)$ 에서 유의한 차이가 나타났다. 각 연령집단 간 차이를 구체적으로 살펴보기 위하여 Scheffé의 방법을 사용하 여 사후검정을 실시한 결과 어머니의 온정의 경우에는 연령집 
단 간 비교가 유의하지 않았지만, 개입의 경우 어머니는 만 3 세 $(M=2.05, S D=0.46)$ 보다 5 세 $(M=2.23, S D=0.48)$ 에게 개 입적인 양육행동을 더 보였다. 실행기능의 경우 연령에 따른 차이가 유의하지 않았으며, 마음이론의 경우 유아의 연령에 따라 어머니가 보고한 유아의 믿음 $(F=12.88, p<.001)$, 지식 $(F$ $=12.23, p<.001)$, 바람 $(F=11.20, p<.001)$, 의도 $(F=10.05, p$ <.001), 감정 $(F=8.03, p<.001)$ 에 대한 이해가 차이를 보였다. Scheffé의 사후검정을 실시한 결과, 연령차는 만 3세와 만 4, 5 세 집단 간 차이에 기인하였으며, 만 4 세(믿음: $M=2.63, S D=$ 0.38 ; 지식: $M=2.88, S D=0.45$; 바람: $M=2.85, S D=0.41$; 의 도: $M=2.82, S D=0.38$; 감정: $M=2.84, S D=0.40$ )와 5세(믿음: $M=2.66, S D=0.42$; 지식: $M=2.95, S D=0.50$; 바람: $M=2.89$, $S D=0.44 ;$ 의도: $M=2.83, S D=0.44 ;$ 감정 $: M=2.88, S D=0.41$ ) 가 만 3 세(믿음: $M=2.42, S D=0.44$; 지식: $M=2.68, S D=0.40$; 바람: $M=2.66, S D=0.40$; 의도: $M=2.63, S D=0.40$; 감정: $M$ $=2.70, S D=0.32)$ 보다 유의하게 높은 마음이론을 보였다. 따 라서 추후 분석에서는 유아의 연령을 통제한 후 변인 간 관계 를 살펴보았다.

\section{변인들 간 상관관계}

유아의 연령을 통제한 후 어머니의 양육행동과 유아의 실행 기능 및 마음이론 간 편상관계수를 산출한 결과, 대부분의 변 인들 사이에서 유의한 상관관계가 나타났다(Table 2). 첫째, 어 머니의 양육행동과 마음이론 간 상관과 관련하여, 어머니의 온정 $(r=.13 \sim .23, p<.01$ 혹은 $p<.001)$ 과 논리적 설명 $(r=.17$ $\sim .31, p<.01$ 혹은 $p<.001)$ 은 마음이론의 모든 하위요인과 유의한 정적 상관을 보여, 어머니가 온정적이고 논리적 설명 을 더 제공할수록 유아는 높은 수준의 마음이론을 보였다. 반 면 어머니의 강압 $(r=-.14 \sim-.20, p<.01$ 혹은 $p<.001)$ 과 방임 $(r=-.17 \sim-.24, p<.01$ 혹은 $p<.001)$ 은 마음이론의 하위요인 인 믿음을 제외한 나머지 하위요인과 부적상관이 있었다. 즉, 어머니의 강압과 방임이 높을수록 유아는 낮은 수준의 마음이 론을 보였다. 어머니의 개입은 마음이론의 하위요인 중 바람 $(r$ $=-.10, p<.05)$ 과 감정 $(r=-.11, p<.05)$ 과 유의한 부적 상관을 보여, 어머니가 개입을 더 많이 할수록 유아는 바람과 감정에 대한 이해가 낮았다.

둘째, 어머니의 양육행동의 하위요인인 온정 $(r=.37 \sim .40, p$ <.001)과 논리적 설명 $(r=.27 \sim .36, p<.001)$ 은 실행기능의 모든 하위요인과 정적상관을 보였다. 즉, 어머니가 온정적인 양육행 동을 보이고 논리적 설명을 더 제공할수록 유아는 높은 수준의
실행기능을 보였다. 반면 어머니의 개입 $(r=-.44 \sim-.50, p<.001)$, 강압 $(r=-.44 \sim-.58, p<.001)$ 및 방임 $(r=-.52 \sim-.62, p<.001)$ 은 실행기능의 모든 하위요인과 부적상관을 보여, 어머니가 개입, 강압 및 방임을 더 할수록 유아는 낮은 실행기능을 보였다.

마지막으로, 유아의 실행기능과 마음이론 간의 상관을 살 펴본 결과, 마음이론의 하위요인 중 믿음을 제외한 모든 하위 요인이 실행기능과 유의한 상관을 보였다. 즉, 실행기능의 하 위요인인 억제 $(r=.20 \sim .27, p<.001)$, 전환 $(r=.16 \sim .23, p<.01$ 혹은 $p<.001)$, 감정조절 $(r=.14 \sim .27, p<.01$ 혹은 $p<.001)$, 작 업 기억 $(r=.26 \sim .32, p<.001)$, 계획 및 조직화 $(r=.26 \sim .30, p$ <.001)는 믿음을 제외한 마음이론의 하위요인과 유의한 정적 상관을 보였다.

\section{측정모형 분석}

연구변인 간 구조적 관계를 검증하기에 앞서, 어머니의 양육 행동과 유아의 실행기능 및 마음이론을 측정하는 하위변인들 이 잠재변인을 잘 측정하고 있는지 살펴보기 위해 확인적 요 인분석(confirmatory factor analysis)을 실시하였다. 잠재변인 중 어머니의 양육행동은 긍정적인 양육행동(온정, 논리적 설명) 과 부정적인 양육행동(개입, 강압, 방임)을 함께 포함하고 있 어, 부정적인 양육행동을 역코딩하여 어머니의 양육행동 점 수가 높을수록 긍정적인 양육행동을 의미하도록 변환하였 다. 확인적 요인분석의 모수추정방식은 최대우도법(maximum likelihood estimation)을 사용하였으며, 모형의 적합도는 $\chi^{2}$ 의 경우 표본의 크기에 민감한 영향을 받을 수 있기 때문에, NFI (Normed Fit Index), TLI (Tucker-Lewis Index), CFI (Comparative Fit Index), RMSEA (Root Mean Square Error of Approximation) 와 같은 다른 적합도 지수를 함께 평가하였다.

측정모형의 적합도는 $\chi^{2}=471.42(d f=86, p<.001), \chi^{2} / d f$ $=5.42, \mathrm{NFI}=.90, \mathrm{TLI}=.90, \mathrm{CFI}=.92, \mathrm{RMSEA}=.11(90 \% \mathrm{CI}$ $=.10, .11$ 로 나타나 특히 RMSEA의 경우 .08 이하(Browne $\&$ Cudeck, 1993)라는 적절한 수준의 적합도 기준을 충족하지 못 하였다. 따라서 수정지수(Modification Index [MI])가 높고 같은 척도를 사용한 전환과 감정 조절의 측정오차 간 공분산을 설 정한 후 재분석한 결과, 모형의 적합도는 $\chi^{2}=237.14(d f=81$, $p<.001), \chi^{2} / d f=2.93, \mathrm{NFI}=.95, \mathrm{TLI}=.96, \mathrm{CFI}=.97$, RMSEA $=.07(90 \% \mathrm{CI}=.06, .08)$ 로 나타났다. 비록 $\chi^{2}$ 값은 유의하였 지만, $\chi^{2} / d f$ 의 값이 3 보다 작고(Kline, 2015), NFI, TLI, CFI는 .90 이상(Marsh \& Hau, 1996), RMSEA는 .08 이하(Browne \& Cudeck, 1993)로 나타나 적절한 수준의 적합도를 보였다. 또한 


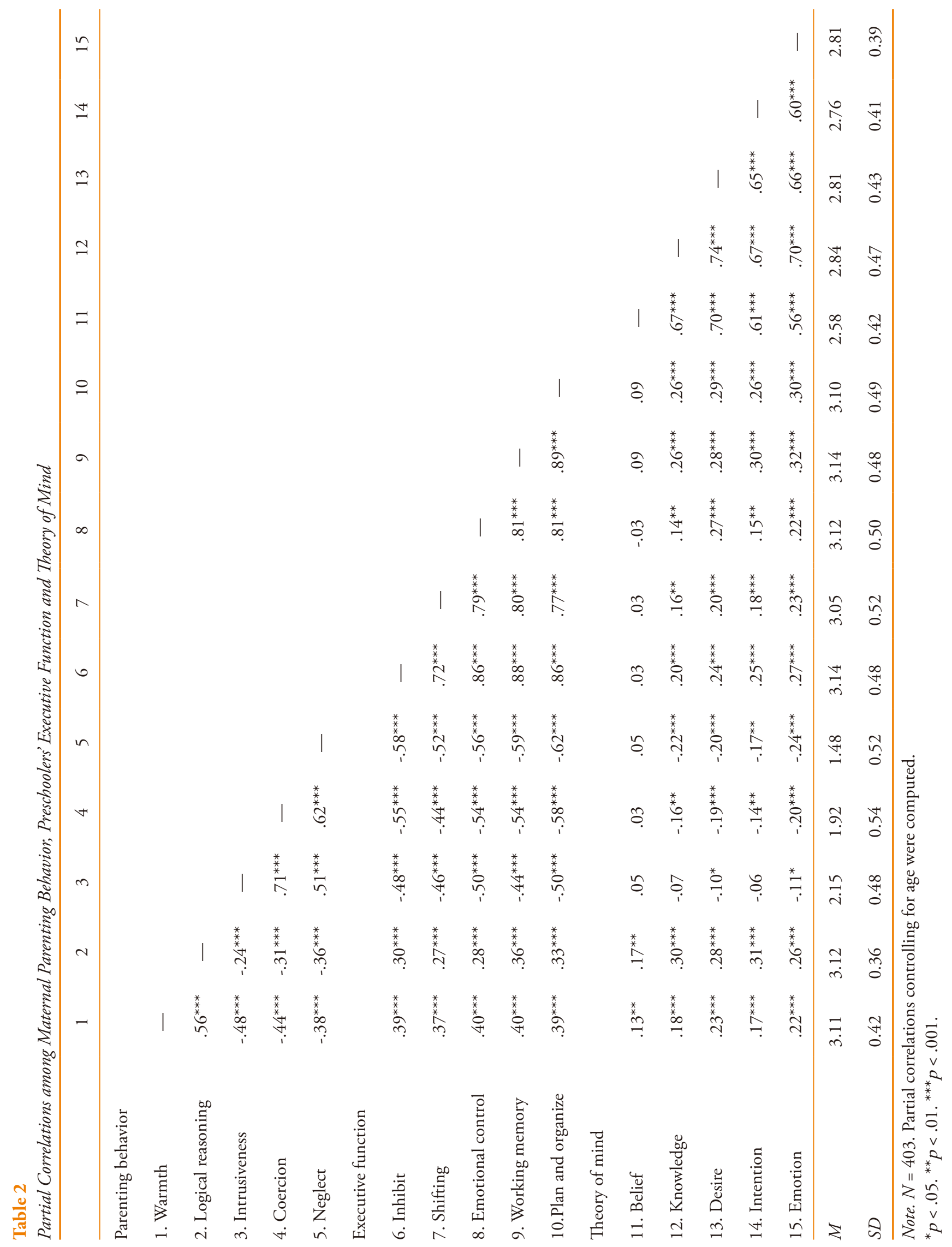




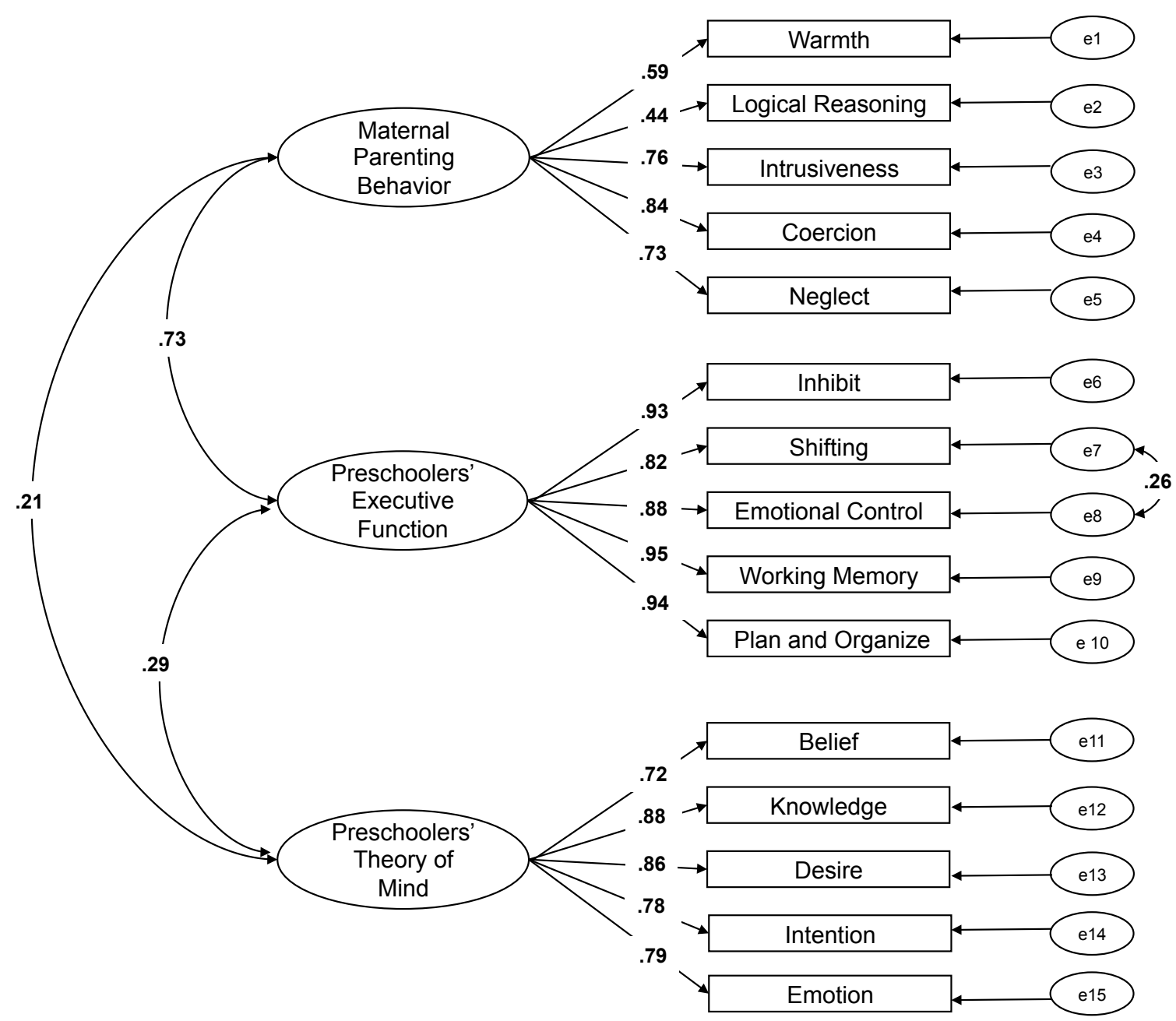

Figure 2. Parameter estimates in the measurement model. Standardized factor loadings were displayed and all were significant at the .001 level.

잠재변인에서 측정변인으로의 표준화된 요인부하량( $\beta$ )은 .44 . 95로 모두 통계적으로 유의하였다(Figure 2). 따라서 측정모 형은 자료를 적절하게 설명하고 있으며, 측정변인이 잠재변인 의 개념을 적절하게 반영하였다.

\section{구조모형 분석}

어머니의 양육행동 및 유아의 실행기능이 유아의 마음이론에 어떠한 경로로 영향을 미치는지를 살펴보기 위해 연령을 통제 한 구조모형을 설정하여 분석하였다. 그 결과, 구조모형의 적 합도는 $\chi^{2}=291.00(d f=94, p<.001), \chi^{2} / d f=3.10, \mathrm{NFI}=.94$, $\mathrm{TLI}=.95, \mathrm{CFI}=.96, \mathrm{RMSEA}=.07(90 \% \mathrm{CI}=.06, .08)$ 로 적절 하였다. 변인들 간의 경로를 살펴본 결과(Table 3; Figure 3), 어 머니의 양육행동이 유아의 마음이론에 미치는 직접적인 영향
은 유의하지 않았다. 어머니의 양육행동이 유아의 실행기능을 통해 유아의 마음이론에 미치는 간접적인 영향을 분석한 결 과, 어머니의 양육행동은 유아의 실행기능 $(\beta=.72, p<.001)$ 에, 유아의 실행기능은 유아의 마음이론에 $(\beta=.29, p<.001)$ 에 유 의한 영향을 미쳤다. 즉, 어머니가 긍정적인 양육행동을 보일 수록, 유아의 실행기능은 높았으며, 실행기능이 높을수록 높 은 수준의 마음이론을 보였다. 간접효과가 통계적으로 유의 한지 살펴보기 위하여 부트스트랩핑 분석을 실시한 결과, 어 머니의 양육행동이 유아의 실행기능을 통해 유아의 마음이론 에 미치는 간접적 영향은 유의하였다 $(\beta=.24, p<.01)$. 마지막 으로, 외생변수가 내생변수의 변량을 설명하는 정도인 다중상 관계수(squared multiple correlation)를 살펴본 결과, 어머니의 양육행동과 유아의 실행기능은 유아의 마음이론의 개인차를 $15.5 \%$ 설명하였으며, 어머니의 양육행동은 유아의 실행기능 
Table 3

Parameter Estimates in the Structural Model

\begin{tabular}{lllllr}
\hline Paths from latent to latent variable & $B$ & $\beta$ & $S E$ & C.R. \\
\hline Parenting behavior $\rightarrow \quad$ Theory of mind & .01 & .02 & .07 & .18 \\
Parenting behavior $\rightarrow \quad$ Executive function & .97 & .72 & .08 & $12.37^{* * *}$ \\
Executive function $\rightarrow \quad$ Theory of mind & .19 & .29 & .05 & $3.64^{* * *}$ \\
\hline
\end{tabular}

Note. $N=403$. Age was controlled in the structural model.

${ }^{* * *} p<.001$.

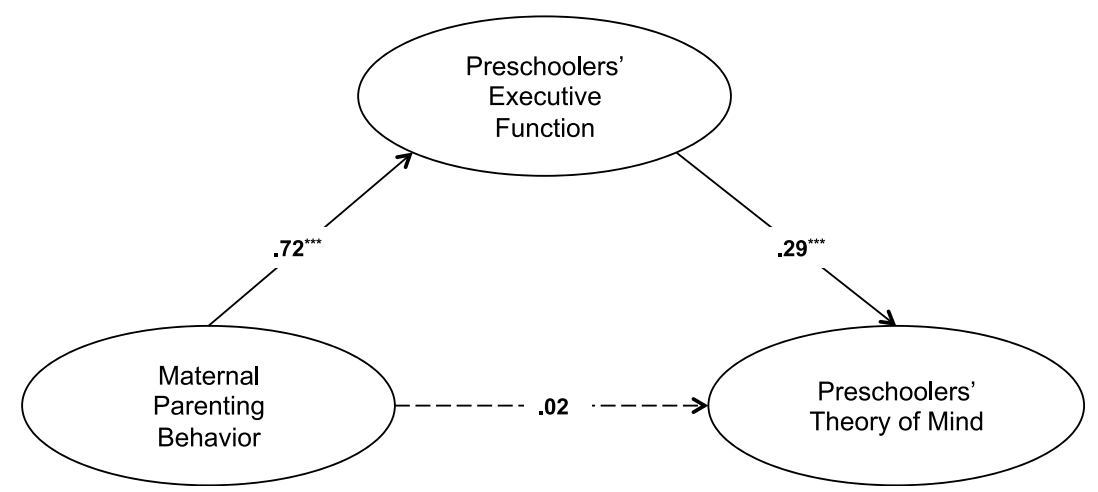

Figure 3. Parameter estimates in the structural model. Standardized parameters were displayed. For brevity, measured variables, controlled variable (age), and associated errors are not shown.

${ }^{* * *} p<.001$.

을 $51.2 \%$ 설명하였다.

\section{는이 믿 결른}

본 연구는 만 3-5세의 유아와 그들의 어머니를 대상으로 어머니 의 양육행동이 유아의 마음이론에 미치는 직접적인 영향과 실 행기능을 통해 미치는 간접적인 영향을 살펴보았다. 유아기 실 행기능과 마음이론 간 관련성에 더해 최근의 종단연구(Carlson, Mandell, \& Williams, 2004; Hughes \& Ensor, 2007)와 훈련 연구 (Benson et al., 2013; Y.-M. Lee \& Park, 2008)의 결과들은 유아기 동안 실행기능의 발달이 마음이론의 발달에 선행됨을 제안하 고 있다. 따라서 본 연구에서는 어머니의 양육행동이 실행기능 의 발달을 촉진하고, 그 결과 마음이론이 향상되는 것으로 가정 한 모형을 설정하여 분석하였다. 본 연구의 연구문제를 중심으 로 그 결과를 요약하고 논의하면 다음과 같다.

구조모형을 분석한 결과 어머니의 양육행동은 유아의 마음 이론에 직접적인 영향을 미치지 않았으며, 유아의 실행기능 을 통한 간접적 영향만이 유의하였다. 양육행동과 마음이론 간 관계를 확인한 대부분의 선행 연구들은 두 변인 간 상관에 기초하였기 때문에 본 연구의 결과와 직접적으로 비교하기는 어려운데, 이러한 연구들에서는 어머니의 민감한 양육행동이 유아의 틀린믿음과제에서의 성공과 관련이 있으며(Symons \&
Clark, 2000), 어머니의 질책(Ruffman et al., 1999)이나 신체적, 언어적 강압(Pears \& Moses, 2003), 논리적 설명(Bae \& Choi, 2002)이 마음이론에서의 개인차와 관련이 있음을 보고하였 다. 본 연구에서도 이와 유사하게, 상관관계 분석에서는 어머 니의 양육행동과 유아의 마음이론 간 상관이 대부분 유의하였 지만, 실행기능이 함께 고려되었을 때 어머니의 양육행동이 마음이론에 미치는 영향은 더 이상 유의하지 않았다. 이러한 결과는 어머니의 양육행동과 유아의 실행기능 간 공분산에 기 인하는 것으로 보인다. 즉, 어머니의 양육행동이 유아가 일상 생활에서 보이는 마음이론과 관련이 있지만, 어머니의 양육행 동과 실행기능을 함께 고려하였을 경우에는 두 변인 간 공분 산이 커 어머니의 양육행동의 영향력이 나타나지 않았을 가능 성이 있다.

반면, 어머니의 양육행동이 유아의 실행기능을 통해 마음 이론에 미치는 간접적인 영향은 유의하여, 어머니가 온정적이 고 논리적인 양육행동을 더 보일수록, 그리고 개입, 강압, 방 임과 같은 부정적인 양육행동을 덜 보일수록 유아가 높은 수 준의 실행기능을 보였으며, 이는 높은 수준의 마음이론으로 이어졌다. 먼저, 어머니의 양육행동이 유아의 실행기능에 미 치는 영향에 관한 본 연구의 결과는 어머니의 자율성 지지나 정서적 지지, 민감성이 유아의 실행기능을 발달시킨다는 연 
구결과들(Blair et al., 2014; Cha, 2015; Hammond et al., 2012; Hughes \& Ensor, 2009; Landry, Miller-Loncar, Smith, \& Swank, 2002; Y.-J. Lee et al., 2014; Moon \& Shin, 2017)이나 어머니의 과보호, 개입이나 비일관적 양육과 같은 부정적인 양육행동 이 유아의 실행기능 발달에 부정적인 영향을 미친다는 연구결 과들(Graziano, 2009; Hughes \& Ensor, 2009)과 일치한다. 어머 니가 온정적 양육행동을 보일수록 유아가 높은 실행기능을 보 이고, 강압적 양육행동을 보일수록 낮은 실행기능을 보인다 는 본 연구의 결과는 뇌 발달과도 관련지어 해석해 볼 수 있는 데, 실행기능과 관련이 있는 것으로 보고되는 전두엽(Garon, Bryon, \& Smith, 2008)이 적절하고 민감한 양육행동을 통한 긍 정적인 정서경험(Glaser, 2000; Kang, 2007)에 의해 촉진된다는 점을 고려해 볼 수 있다. 즉, 어머니의 온정적 양육행동은 유아 가 긍정적인 정서를 더 경험하게 하여 이로 인해 유아의 전두 엽이 활성화되어 실행기능이 발달할 수 있다. 반대로 화를 내 거나 신체적 처벌과 같은 강압적 양육행동은 유아의 부정적인 정서경험을 증가시키고, 전두엽이 덜 활성화되도록 하여 실행 기능 발달에 부정적인 영향을 줄 수 있을 것이다. 또한 어머니 의 지나친 개입이나 방임은 주변 환경을 통한 경험의 기회를 제한하여 실행기능의 발달을 저해할 수 있으며, 어머니가 사 회적인 기준이나 규칙 및 적절한 행동을 합리적이고 논리적인 설명을 통해 가르칠 경우 유아는 이러한 기준을 내면화하게 되어 실행기능이 요구되는 상황에서 이를 더 효과적으로 사용 할 수 있음을 시사한다.

다음으로, 유아의 실행기능은 유아의 마음이론에 유의한 정적 영향을 미쳐, 유아의 실행기능 수준이 높을수록 마음이 론이 더 높은 것으로 나타났다. 이러한 결과는 실행기능과 마음이론 간 밀접한 관련성을 보고한 선행연구들(Carlson \& Moses, 2001; Carlson, Moses, \& Hix, 1998; Devine \& Hughes, 2014)의 결과와 일치하는 것으로, 알고 있는 사실을 억제하거 나, 자신의 입장에서 타인의 입장으로 전환하는 등 억제나 주 의전환과 같은 실행기능이 발달하면서 마음이론이 발달한다 는 주장(Russell, 1996)과 같은 맥락이다. 국내에서 실시된 연구 들은 다소 일관적이지 않은 결과를 보고하고 있는데, 두 변인 간 관련성을 입증한 연구(H. Lee, 2013)가 있는 반면, 관련성 을 발견하지 못한 연구들도 보고되고 있다(Gwon \& Lee, 2012; H. Lee, 2011). 선행연구들은 이러한 차이가 국내 유아들이 서 구의 유아들보다 높은 실행기능을 가지고 있지만 마음이론은 큰 차이를 보이지 않는 것에 기인하는 것으로 해석하였는데, 본 연구의 유아들의 경우 실행기능의 수준이 마음이론의 수준 보다 높았지만 두 변인 간 관련성은 유의하여 이러한 해석을
지지하지는 않았다. 이러한 차이는 앞서 언급한 것처럼 실행 기능과 마음이론을 측정한 도구에서의 차이에 기인할 수 있으 며, 추후 후속 연구들을 통해 과제 수행과 척도를 통해 측정한 실행기능과 마음이론의 유사점과 차이점에 대한 검증들이 지 속적으로 이루어질 필요가 있다.

종합하면, 본 연구에서 어머니의 양육행동과 유아의 마음 이론 간의 유의한 상관관계가 발견되었으나, 유아의 실행기능 과 어머니의 양육행동을 함께 고려한 구조모형에서는 어머니 의 양육행동의 직접적인 영향은 유의하지 않았으며, 유아의 실행기능을 통한 간접적 영향만이 유의하였다. 이는 마음이론 에 영향을 미치는 요인을 살펴볼 때, 어머니의 양육행동과 같 은 환경적 요인과 실행기능과 같은 개인내적요인을 함께 살펴 볼 필요가 있음을 강조한다. 즉, 온정과 논리적 설명과 같은 긍 정적인 양육행동은 유아의 실행기능 발달에 긍정적인 영향을 미치며, 강압이나 개입 및 방임과 같은 부정적인 양육행동은 실행기능 발달에 부정적인 영향을 주게 되어 그 결과 마음이 론을 저해한다는 본 연구의 결과는 유아의 사회적 적응과 관 련하여 중요한 시사점을 갖는다. 이를 통해 유아의 긍정적 발 달을 위해서는 강압과 방임, 개입과 같은 부정적 양육행동을 지양하고, 온정적이고 논리적 설명을 제공하는 긍정적 양육행 동이 강조되어야 한다는 것을 알 수 있다.

본 연구의 제한점과 후속연구를 위한 제언은 다음과 같다. 첫째, 본 연구에서 사용된 실행기능 척도의 경우 국내외에서 활발하게 사용되고 있지만 마음이론 척도는 보다 최근에 개발 되어 후속연구에서 보다 다양한 표본을 사용하여 연구가 이루 어질 필요가 있다. 둘째, 본 연구에서 유아의 마음이론을 측정 하기 위해 사용한 척도는 국외에서 제작된 척도로(Tahiroglu et al., 2014), 기존에 널리 사용된 마음이론 과제와 유의한 상관 을 보여 그 타당성이 입증된 척도이다. 본 연구에서는 번역, 역 번역 절차를 통해 척도를 사용하였지만, 후속 연구에서는 국 내 상황에서 본 척도가 신뢰롭고 타당하게 사용될 수 있는지 여부를 검사-재검사 신뢰도, 마음이론 과제와의 상관을 통한 공인 타당도 등을 살펴봄으로써 확립할 필요가 있다. 셋째, 본 연구에서는 모든 변인이 어머니 보고를 통해 측정되었기 때문 에, 이로 인해 변인 간 관계가 과잉 추정되었을 가능성이 있다. 특히 실행기능과 마음이론의 경우 과제수행을 통한 측정이 유 아의 실제 능력을 측정하는 반면, 어머니 보고를 통한 측정은 유아의 능력에 대한 어머니의 지각을 측정하기 때문에 어머니 의 특성이 반영될 수 있다. 따라서 후속 연구에서는 실행기능 과 마음이론 각각을 과제수행과 부모보고를 함께 사용하여 측 정하여 두 변인 간 관련성을 보다 통합적으로 살펴볼 필요가 
있다. 마지막으로 본 연구에서는 어머니 보고를 통해 실행기 능과 마음이론을 측정하였지만, 후속 연구에서는 아버지나 교 사 등 보다 다양한 보고자를 통해 측정한다면 유아의 실행기 능과 마음이론을 이해하는 데 도움이 될 것이다.

이러한 제한점에도 불구하고 본 연구는 다음과 같은 몇 가 지 의의를 갖는다. 첫째, 본 연구에서는 국외에서 최근 개발된 마음이론 척도를 국내에서는 처음으로 번안하여 사용하였으 며, 이를 통해 마음이론에 관한 후속연구들이 활성화 될 수 있 기를 기대한다. 둘째, 본 연구에서는 국내에서 비교적 최근에 연구되기 시작한 실행기능과 마음이론을 다양한 양육행동의 하위요인들과 함께 살펴보았다. 이 세 변인들 간의 관계를 살 펴본 선행연구들이 부족하기 때문에, 본 연구를 통해 실행기 능과 마음이론 연구를 확장하였다. 셋째, 본 연구에서는 어머 니의 양육행동이 유아의 실행기능을 통해 마음이론에 미치는 영향을 확인함으로써, 유아기 실행기능 발달의 중요성과 함께 유아기 자녀를 둔 어머니에게 올바른 양육행동의 중요성을 환 기시킬 수 있을 것이며, 어머니의 양육행동의 중요성을 다시 한 번 확인하였다는 데 의의가 있다. 이를 통해 현장에서는 올 바른 훈육의 중요성을 강조하는 부모교육 자료로, 학문분야에 서는 실행기능과 마음이론의 연구를 활성화하기 위한 자료로 활용되기를 기대한다.

\section{Acknowledgements}

This work was supported by the Ministry of Education of the Republic of Korea and the National Research Foundation of Korea (NRF-2015S1A5A8016816).

\section{Notes}

This article is a part of the first author's master's thesis submitted in 2016.

\section{Conflict of Interest}

No potential conflict of interest relevant to this article was reported.

\section{References}

\section{In English}

Benson, J. E., Sabbagh, M. A., Carlson, S. M., \& Zelazo, P. D. (2013). Individual differences in executive functioning predict preschoolers' improvement from theory-of-mind training. Developmental Psychology, 49(9), 1615-1627. doi:10.1037/ a0031056

Bernier, A., Carlson, S. M., \& Whipple, N. (2010). From external regulation to self-regulation: Early parenting precursors of young children's executive functioning. Child Development, 81(1), 326-339. doi:10.1111/j.1467-8624.2009.01397.x

Blair, C., Granger, D. A., Willoughby, M., Mills-Koonce, R., Cox, M., Greenberg, M. T., . . . \& the Family Life Project Investigators. (2011). Salivary cortisol mediates effects of poverty and parenting on executive functions in early childhood. Child Development, 82(6), 1970-1984. doi:10.1111/j.1467-8624.2011.01643.x

Blair, C., Raver, C. C., Berry, D. J., \& Family Life Project Investigators. (2014). Two approaches to estimating the effect of parenting on the development of executive function in early childhood. Developmental Psychology, 50(2), 554-565. doi:10.1037/a0033647

Browne, M. W., \& Cudeck, R. (1993). Alternative ways of assessing model fit. In K. A. Bollen \& J. S. Long (Eds.), Testing structural equation models (pp. 136-162). Newbury Park, CA: Sage Publications.

Carlson, S. M. (2005). Developmentally sensitive measures of executive function in preschool children. Developmental Neuropsychology, 28(2), 595-616. doi:10.1207/s15326942dn2802_3

Carlson, S. M., Mandell, D. J., \& Williams, L. (2004). Executive function and theory of mind: Stability and prediction from ages 2 to 3. Developmental Psychology, 40(6), 1105-1122. doi:10.1037/0012-1649.40.6.1105

Carlson, S. M., \& Moses, L. J. (2001). Individual differences in inhibitory control and children's theory of mind. Child Development, 72(4), 1032-1053. doi:10.1111/1467-8624.00333

Carlson, S. M., Moses, L. J., \& Claxton, L. J. (2004). Individual differences in executive functioning and theory of mind: An investigation of inhibitory control and planning ability. Journal of Experimental Child Psychology, 87(4), 299-319. doi:10.1016/j.jecp.2004.01.002

Carlson, S. M., Moses, L. J., \& Hix, H. R. (1998). The role of inhibitory processes in young children's difficulties with deception and false belief. Child Development, 69(3), 672691. doi:10.1111/j.1467-8624.1998.tb06236.x

Cassidy, K. W., Werner, R. S., Rourke, M., Zubernis, L. S., \& Balaraman, G. (2003). The relationship between 
psychological understanding and positive social behaviors. Social Development, 12(2), 198-221. doi:10.1111/14679507.00229

Devine, R. T., \& Hughes, C. (2014). Relations between false belief understanding and executive function in early childhood: A meta-analysis. Child Development, 85(5), 1777-1794. doi: $10.1111 /$ cdev. 12237

Flavell, J. H., Flavell, E. R., \& Green, F. L. (1983). Development of the appearance-reality distinction. Cognitive Psychology, 15(1), 95-120. doi:10.1016/0010-0285(83)90005-1

Frye, D., Zelazo, P. D., \& Palfai, T. (1995). Theory of mind and rule-based reasoning. Cognitive Development, 10(4), 483527. doi:10.1016/0885-2014(95)90024-1

Garon, N., Bryson, S. E., \& Smith, I. M. (2008). Executive function in preschoolers: A review using an integrative framework. Psychological Bulletin, 134(1), 31-60. doi:10.1037/00332909.134.1.31

Gerstadt, C. L., Hong, Y. J., \& Diamond, A. (1994). The relationship between cognition and action: Performance of children 31/2-7 years old on a stroop-like day-night test. Cognition, 53(2), 129-153. doi:10.1016/0010-0277(94)90068-X

Gioia, G. A., Isquith, P. K., Guy, S. C., \& Kenworthy, L. (2000). Test review behavior rating inventory of executive function. Child Neuropsychology, 6(3), 235-238. doi:10.1076/ chin.6.3.235.3152

Glaser, D. (2000). Child abuse and neglect and the brain: A review. Journal of Child Psychology and Psychiatry, 41(1), 97-116. doi:10.1017/S0021963099004990

Graziano, P. A. (2009). Developmental trajectories of "hot" executive functions across early childhood: Contributions of maternal behavior and temperament (Doctoral dissertation). Retrieved from https://libres.uncg.edu/ir/uncg/listing.aspx?id=2315

Hadwin, J., Baron-Cohen, S., Howlin, P., \& Hill, K. (1996). Can we teach children with autism to understand emotions, belief, or pretence? Development and Psychopathology, 8, 345-365. doi:10.1017/S0954579400007136

Hammond, S. I., Müller, U., Carpendale, J. I. M., Bibok, M. B., \& Liebermann-Finestone, D. P. (2012). The effects of parental scaffolding on preschoolers' executive function. Developmental Psychology, 48(1), 271-281. doi:10.1037/ a0025519

Harris, P. L. (2006). Social cognition. In D. Kuhn \& R. S. Siegler (Eds.), Handbook of child psychology: Vol. 2. Cognition, perception, and language. 6th ed (pp. 811-858). New York: Wiley.

Hongwanishkul, D., Happaney, K. R., Lee, W. S. C., \& Zelazo, P. D. (2005). Assessment of hot and cool executive function in young children: Age-related changes and individual differences. Developmental Neuropsychology, 28(2), 617-644. doi:10.1207/s15326942dn2802_4
Hughes, C., Adlam, A., Happé, F., Jackson, J., Taylor, A., \& Caspi, A. (2000). Good test-retest reliability for standard and advanced false-belief tasks across a wide range of abilities. Journal of Child Psychology and Psychiatry, 41(4), 483-490. doi:10.1111/1469-7610.00633

Hughes, C., \& Ensor, R. (2007). Executive function and theory of mind: Predictive relations from ages 2 to 4 . Developmental Psychology, 43(6), 1447-1459. doi:10.1037/0012-1649.43.6.1447

Hughes, C. H., \& Ensor, R. A. (2009). How do families help or hinder the emergence of early executive function? New Directions for Child and Adolescent Development, 2009(123), 35-50. doi:10.1002/cd.234

Isquith, P. K., Gioia, G. A., \& Espy, K. A. (2004). Executive function in preschool children: Examination through everyday behavior. Developmental Neuropsychology, 26(1), 403-422. doi:10.1207/s15326942dn2601_3

Jacques, S., \& Zelazo, P. D. (2001). The Flexible Item Selection Task (FIST): A measure of executive function in preschoolers. Developmental Neuropsychology, 20(3), 573-591. doi:10. 1207/875656401753549807

Kline, R. B. (2015). Principles and practice of structural equation modeling (4th edition). New York: Guilford Press.

Landry, S. H., Miller-Loncar, C. L., Smith, K. E., \& Swank, P. R. (2002). The role of early parenting in children's development of executive processes. Developmental Neuropsychology, 21(1), 15-41. doi:10.1207/s15326942dn2101_2

Marsh, H. W., \& Hau, K.-T. (1996). Assessing goodness of fit: Is parsimony always desirable? The Journal of Experimental Education, 64(4), 364-390. doi:10.1080/00220973.1996.1 0806604

Oh, S., \& Lewis, C. (2008). Korean preschoolers' advanced inhibitory control and its relation to other executive skills and mental state understanding. Child Development, 79(1), 80-99. doi:10.1111/j.1467-8624.2007.01112.x

Pears, K. C., \& Moses, L. J. (2003). Demographics, parenting, and theory of mind in preschool children. Social Development, 12(1), 1-20. doi:10.1111/1467-9507.00219

Perner, J. (1991). Understanding the representational mind. Cambridge, MA: MIT Press.

Premack, D., \& Woodruff, G. (1978). Does the chimpanzee have a theory of mind? Behavioral and Brain Sciences, 1(4), 515526. doi:10.1017/S0140525X00076512

Rakoczy, H. (2010). Executive function and the development of belief-desire psychology. Developmental Science, 13(4), 648661. doi:10.1111/j.1467-7687.2009.00922.x

Ruffman, T., Perner, J., \& Parkin, L. (1999). How parenting style affects false belief understanding. Social Development, 8(3), 395-411. doi:10.1111/1467-9507.00103

Russell, J. (1996). Agency: Its role in mental development. Hove, UK: Erlbaum. 
Sabbagh, M. A., \& Taylor, M. (2000). Neural correlates of theoryof-mind reasoning: An event-related potential study. Psychological Science, 11(1), 46-50. doi:10.1111/14679280.00213

Symons, D. K., \& Clark, S. E. (2000). A longitudinal study of mother-child relationships and theory of mind in the preschool period. Social Development, 9(1), 3-23. doi:10.1111/1467-9507.00108

Tahiroglu, D., Moses, L. J., Carlson, S. M., Mahy, C. E. V., Olofson, E. L., \& Sabbagh, M. A. (2014). The Children's Social Understanding Scale: Construction and validation of a parent-report measure for assessing individual differences in children's theories of mind. Developmental Psychology, 50(11), 2485-2497. doi:10.1037/a0037914

Toplak, M. E., West, R. F., \& Stanovich, K. E. (2013). Practitioner review: Do performance-based measures and ratings of executive function assess the same construct? Journal of Child Psychology and Psychiatry, 54(2), 131-143. doi:10. 1111/jcpp. 12001

Viden, P. G. (2001). Parenting attitudes and children's understanding of mind: A comparison of Korean American and AngloAmerican families. Cognitive Development, 16(3), 793-809. doi:10.1016/S0885-2014(01)00059-4

Wellman, H. M., Cross, D., \& Watson, J. (2001). Meta-analysis of theory-of-mind development: The truth about false belief. Child Development, 72(3), 655-684. doi:10.1111/14678624.00304

Welsh, M. C. (1991). Rule-guided behavior and self-monitoring on the tower of hanoi disk-transfer task. Cognitive Development, 6(1), 59-76. doi:10.1016/0885-2014(91)90006-Y

Welsh, M. C., Pennington, B. F., \& Groisser, D. B. (1991). A normative-developmental study of executive function: A window on prefrontal function in children. Developmental Neuropsychology, 7(2), 131-149. doi:10.1080/87565649109 540483

Wimmer, H., \& Perner, J. (1983). Beliefs about beliefs: Representation and constraining function of wrong beliefs in young children's understanding of deception. Cognition, 13(1), 103-128. doi:10.1016/0010-0277(83)90004-5

Zelazo, P. D., \& Müller, U. (2002). Executive function in typical and atypical development. In U. Goswami (Ed.), Handbook of childhood cognitive development (pp. 445-469). Oxford, UK: Blackwell. doi:10.1002/9780470996652.ch20

\section{In Korean}

Ahn, H. J., Kim, S. L., \& Lee, S. J. (2012). Study on the relationship among children's theory of mind, social competence, and emotional intelligence. Journal of Korean Child Care and Education, 8(5), 179-202.
Bae, K., \& Choi, B. (2002). The relationship between preschoolers' theory-of-Mind and relative variables. Korean Journal of Early Childhood Education, 22(2), 195-216.

Cha, K. (2015). Maternal interaction behaviors and the development of executive functions among Korean preschoolers. Korean Journal of Early Childhood Education, 35(2), 117-141.

Chi, S.-A., \& Kim, S.-H. (2015). The structural relationships among young children's theory of mind, hot executive function, cognitive ability and self-esteem. Early Childhood Education Research \& Review, 19(4), 5-28.

Chung, D.-H. (2011). Daily stress, theory of mind and perspective taking ability of 4 or 5 year-old children. The Journal of Child Education, 20(2), 207-220.

Ghim., H.-R. (1997). Development of children's theory of mind: Children's understanding of false belief. Korean Journal of Developmental Psychology, 10(1), 74-91.

Gwon, E.-Y., \& Lee, H. (2012). Development of deception, false belief and executive function in children. The Korean Journal of Developmental Psychology, 25(2), 165-184.

Kang, E.-H. (2007). Positive psychology, neuroscience, and heritability. The Korean Journal of Stress Research, 15(3), 221-225.

Lee, H. (2011). Theory of mind and executive function in Korean children. The Korean Journal of Developmental Psychology, 24(4), 99-113.

Lee, H. (2013). The development of inhibitory control and theory of mind in Korean children. The Korean Journal of Developmental Psychology. 26(1), 293-311.

Lee, J. (2005). A longitudinal study on relationships among false belief, early theory of mind, pretend play, and executive function. The Korean Journal of Developmental Psychology, 18(3), 81-103.

Lee, S.-J. (2012). The relationship of cognitive styles to theory of mind acquisition and self-concept formation. Korean Journal of Early Childhood Education, 32(4), 161-180.

Lee, Y.-M., Kim, S.-H., Kim, J.-H., Kim, B., Wang, H.-Y., Cho, Y.-J., . . . Kim, C. (2015). A study of the relationships between problem behavior and preschool adaptation, peer relation, ego-resilience, and theory of mind. Korean Education Inquiry, 33(2), 135-159.

Lee, Y.-J., Kong, Y.-S., \& Lim, J.-Y. (2014). The effects of parenting behaviors on preschoolers' executive function. Journal of Korean Home Management Association, 32(1), 1326.

Lee, Y.-M., \& Park, Y. (2008). The role of executive function in children`s understanding of false belief. The Korean Journal of Developmental Psychology, 21(4), 57-73.

Moon, J., \& Shin, N. (2017). The effects of maternal autonomy support on preschoolers' emotional and social competence: The mediating effect of preschoolers' executive function. 
Korean Journal of Child Studies, 38(6), 17-33.

$\mathrm{Na}$, J. (2012). Maternal and paternal parenting behaviors affecting preschooler's social competence (Unpublished master's thesis). Ewha Womans University, Seoul, Korea.

Rhee, S. (2012). The study for the development and validation of Parenting Behavior Scale: Parents with school-age children (Doctoral dissertation). Retrieved from http://dcollection. ewha.ac.kr/common/orgView/000000069710

Seo, J., \& Park, H. (2011). The effects of emotional intelligence on executive function: A comparison between normal children and attention deficit children. Journal of Cognitive Enhancement and Intervention, 2(1), 99-126.

Shin, E.-S. (2005). Relationships among theory of mind, decontexutlization in pretend play, language, executive function, and central coherence in young children. Korean Journal of Early Childhood Education, 25(1), 65-90.

Song, Y. J. (1999). Children's understanding of other's beliefs.
Korean Journal of Child Studies, 20(1), 45-59.

Yoo, K.-S., \& Park, H.-J. (2008). The relationship between children's false belief tasks and executive functioning tasks based on theory of mind. The Journal of Child Education, 17(3), 149-159.

Moonyoung Jang

http://orcid.org/0000-0002-1557-7262

Nana Shin

Received December 31, 2017

Revision received February 4, 2018

Accepted February 18, 2018 